\title{
Comportamiento productivo y reproductivo al parto $y$ al destete en cerdas de siete líneas genéticas
}

\section{Productive and reproductive performance at farrowing and at weaning of sows of seven genetic lines}

\author{
Carlos Alberto García-Munguíaa, Agustín Ruíz-Floresb, Rufino López-Ordazb, Alberto \\ Margarito García-Munguíaa, Luis Arturo I barra-J uáreza
}

\begin{abstract}
RESUMEN
El objetivo del estudio fue evaluar los efectos de línea genética (LG), número de parto (NP) y sala de parto (S) en el tamaño de la camada nacida viva (TCNV), el número de lechones nacidos muertos por camada (LNM), el tamaño de la camada al nacimiento (TCN) y al destete (TCD), los pesos de la camada al nacimiento (PCN) y al destete (PCD), el consumo diario de alimento de la cerda (CDA) y las pérdidas de peso (PPL) y grasa dorsal (PGD) de la cerda en la lactancia. Además de los efectos fijos LG, NP y S, el modelo incluyó las covariables TCN para PCN y TCD para PCD. Se encontraron diferencias $(P<0.0026)$ entre $L G$ para TCN, TCNV, LNM y CDA. El NP sólo fue significativo $(P<0.0001)$ para CDA, S sólo lo fue $(P<0.0380)$ para $L N M$. Las cerdas de tres o más partos tuvieron mayor CDA (4.5 $\pm 0.2 \mathrm{~kg})$ que las de primero o segundo partos $(3.4 \pm 0.2 \mathrm{~kg})$. Se requiere reforzar la atención al parto y durante la lactancia para reducir la muerte de lechones al parto y en la lactancia; así como evitar que la cerda pierda demasiado peso y grasa dorsal con el fin de reducir el deterioro del comportamiento productivo y reproductivo postdestete.
\end{abstract}

PALABRAS ClAVE: Productividad al parto, Parámetros reproductivos, Cerdas, Parto, Destete.

\begin{abstract}
This research aimed to study the effects of genetic line (GL), farrowing room (FR) and number of parity (NP) on the productive and reproductive performance at farrowing and weaning of sows of seven genetic lines. The response variables were total litter size at farrowing (TLSF) and at weaning (TLSW), pigs born alive (PBA), stillbirth (PBD), litter weight at farrowing (LWF) and at weaning (LWW), sow average food intake (FI), and sow weight (SWL), and back fat (BFL) loss during lactation. Besides the fixed effects of GL, NP, and FR, the model also included the covariates TLSF for LWF, and TLSW for LWW. There were significant differences $(P<0.0026)$ among GL for TLSF, PBA, PBD, and FI. Parity was important $(P<0.0001)$ only for $F I$, and FR was $(P<0.038)$ for PBD. Sows of three or more parities had higher FI $(4.5 \pm 0.2 \mathrm{~kg})$ than those of one and two $(3.4 \pm 0.2 \mathrm{~kg})$. It is needed more attention at farrowing and during lactation in order to reduce death of piglets both at farrowing and during lactation. Back fat and weight loss of sows during lactation should be reduced in order to avoid deterioration of post-weaning productive and reproductive performance.
\end{abstract}

KEY WORDS: Productive performance, Genetic line, Sows, Farrowing, Weaning.

\section{INTRODUCCIÓN}

Un comportamiento productivo y reproductivo satisfactorio de las cerdas es necesario para la

\section{INTRODUCTION}

A satisfactory productive and reproductive sows' performance is important for the success

Recibido el 8 de abril de 2013. Aceptado el 20 de mayo de 2013.

a Genómica Alimentaria, Universidad de la Ciénega del Estado de Michoacán de Ocampo. México.

b Posgrado en Producción Animal, Departamento de Zootecnia, Universidad Autónoma Chapingo, Carretera México-Texcoco km 38.5. Chapingo, 56230, Estado de México. México. arf@correo.chapingo.mx. Correspondencia al segundo autor. 
consecución del éxito en una empresa porcina. Existen varios indicadores objetivos de este comportamiento, entre los que se encuentran el tamaño de la camada al nacimiento y al destete, el número de partos por hembra por año, el número de lechones destetados por hembra por año y el número de cerdos vendidos por hembra por año. Niveles bajos en estas variables pueden resultar no solamente en un bajo aprovechamiento de la cerda, sino que también limitarán la posibilidad de mejoramiento genético de la piara(1).

Las características reproductivas en general son de baja heredabilidad(2), por lo que gran parte de la mejoría en estas variables se puede conseguir reforzando las buenas prácticas de manejo. Un aspecto importante de este manejo es la alimentación de la cerda en la gestación y la lactancia; un manejo deficiente, especialmente en el primer parto puede tener repercusiones hasta el tercero(3). El comportamiento reproductivo post-destete generalmente se deteriora $(P<0.05)$ con pérdidas de 12.9 a $28.4 \mathrm{~kg}$ de peso vivo de la cerda al final de la lactancia(4). Factores como raza de la hembra pueden no influir directamente en la pérdida de grasa dorsal; sin embargo, el número de parto, especialmente los dos primeros, así como el tamaño de la camada y la ganancia de peso de la camada tienen un efecto importante $(P<0.05)$ en las pérdidas de grasa dorsal y de condición corporal de la hembra lactante(5).

Los sistemas de alojamiento también influyen en el comportamiento productivo de los cerdos, Sulbaran et al(6) encontraron diferencias en el crecimiento de cerdos del nacimiento a finalización dependiendo del tipo de alojamiento. Por su parte, Segura et al(7) observaron mayor mortalidad en lechones nacidos en la época de nortes, cuando las condiciones ambientales son más adversas. Con el objetivo de identificar áreas de mejora en la granja, en este estudio se evaluaron los efectos de línea genética, número de parto de la cerda y sala de parto, en el comportamiento productivo y reproductivo achievement in a swine enterprise. There are several objective indicators of this performance, which include litter size at birth and at weaning, number of farrowings per female per year, number of piglets weaned per female per year and the number of pigs sold per female per year. Low levels in these variables can result not only in a low sow productivity, but it will also limit the possibility of genetic improvement of the herd(1).

The reproductive traits are generally of low heritability(2) therefore much of the improvement in these variables can be obtained by strengthening good management practices. An important aspect of this management is feeding during sow pregnancy and lactation; poor management, especially at first partum can affect up to the third(3). Reproductive performance post-weaning usually deteriorates $(P<0.05)$ with losses from 12.9 to $28.4 \mathrm{~kg}$ of live weight of the sow at the end of lactation(4). Factors such as female breed may not directly influence back fat loss; however, the number of parity, especially the first two, as well as litter size and litter weight gain have a significant effect $(P<0.05)$ in back fat losses and body condition of the lactating sow(5).

Housing systems have also an influence on the productive pig performance. Sulbaran et al(6) found differences in pigs growth from birth to finish depending on the type of accommodation. For his part, Segura et al(7) observed increased mortality in piglets born in the windy season, when environmental conditions are more severe. In order to identify areas for improvement on the farm, this study assessed the effects of genetic line, number of parity and farrowing room in the productive and reproductive performance of sows at birth and at weaning of seven genetic lines.

\section{MATERIALS AND METHODS}

The study was conducted at a swine seedstock farm located in the State of Sonora, Mexico, at an altitude of $35 \mathrm{~m}$ and climate BW ( $\left.\mathrm{h}^{\prime}\right) \mathrm{hw}$ 
de cerdas al nacimiento y al destete de siete líneas genéticas.

\section{MATERIALES Y MÉTODOS}

El estudio se realizó en una granja porcina productora de pie de cría ubicada en el estado de Sonora, México, a una altitud de $35 \mathrm{~m}$ y clima $B W\left(h^{\prime}\right) h w\left(e^{\prime}\right)$ de acuerdo con la clasificación de Koppen modificada(8), con temperatura media anual de $24.7{ }^{\circ} \mathrm{C}$ y precipitación media anual de $382.7 \mathrm{~mm}$.

La granja tiene un proceso de producción tecnificado, con 1,125 reproductoras de siete líneas genéticas, de las cuales 850 estuvieron gestantes, 85 vacías, 60 primerizas, 130 lactando, además de 30 sementales en producción y 25 en adaptación. La información se registró en cinco salas de parto, de cerdas de distinto número de parto de siete líneas genéticas (L1 a L7). Las cerdas de las siete líneas genéticas se distribuyeron aleatoriamente en las cinco salas de parto. El esquema de cruzamientos de la granja determinó la línea genética de la cerda y del semental, dependiendo si la progenie sería de línea materna o de semental terminal.

El manejo de las cerdas lactantes incluyó el lavado y desinfección de las maternidades, previo a la entrada de las hembras. Los grupos de parto se manejaron con el esquema Todo Adentro/Todo Afuera. Al nacer, los lechones recibieron un manejo que incluyó limpieza, corte y desinfección de ombligo, identificación, pesaje y sexado. Las camadas se estandarizaron por número de lechones en las primeras $48 \mathrm{~h}$ de nacidos, por lo que los efectos maternos para las características al destete no se obtendrían de manera insesgada. El destete se realizó a los $16.1 \pm 2.5 \mathrm{~d}$.

El alimento se ofreció varias veces a las cerdas dependiendo de su condición fisiológica, corporal, y de la temperatura ambiental durante el día. Los lechones recibieron alimento sólido y fresco a partir de los cinco días de edad de $\left(e^{\prime}\right)$ according to the modified Köppen classification(8), with average annual temperature of $24.7{ }^{\circ} \mathrm{C}$ and average annual rainfall of $382.7 \mathrm{~mm}$.

The farm has a technical production system, with 1,125 sows in production of seven genetic lines, 850 were pregnant, 85 open, 60 of first parity, 130 lactating, as well as 30 boars in production and 25 in adaptation. The information was recorded in five farrowing rooms, from sows of different number of parity from the seven genetic lines (L1 to L7). The sows of the genetic lines were randomly distributed in the five parity rooms. Crossbreeding scheme of the farm determined the genetic line of the sow and the boar, depending if the progeny would be from maternal line or terminal for stud.

Management of lactating sows included washing and disinfection of maternity rooms, prior to the entry of females. Labor groups were handled with the all in/all out scheme. At birth, piglets received a management that included cleaning, cutting and disinfection of navel, identification, weighing and sexing. Litters were standardized by number of piglets within the first $48 \mathrm{~h}$ of birth, so maternal effects for weaning features would not be obtained in unbiased way. Weaning was at $16.1 \pm 2.5 \mathrm{~d}$.

Feed was offered several times to sows depending on their physiological, body condition, and the temperature during the day. Piglets received solid and fresh food from the d-5 of age frequently in small amounts; water was available at all times.

The variables analyzed were: total litter size at farrowing (TLSF), and at weaning (TLSW), piglets born alive (PBA), piglets born dead (PBD), litter weights at farrowing (LWF), and at weaning (LWW), daily feed intake of the sow $(\mathrm{FI})$, sow weight loss (SWL), and back fat loss during lactation (BFL).

Sows were grouped by number of parity (NP) in the following way: first and second parities 
manera frecuente en pequeñas cantidades, el agua estuvo disponible todo el tiempo.

Las variables analizadas fueron tamaño de la camada al nacimiento (TCN) y al destete (TCD), tamaño de la camada nacida viva (TCNV), número de lechones nacidos muertos por camada (LNM), pesos de la camada al nacimiento (PCN) y al destete (PCD), consumo diario de alimento de la cerda (CDA) y pérdida de peso (PPL) y grasa dorsal (PGD) de la cerda en la lactancia.

Las cerdas se agruparon por número de parto de la siguiente manera: a las de primero y segundo partos se les asignó el número de parto 1, a las de tres o más el número 2, ninguna hembra tuvo más de siete partos; se considera que las hembras de partos uno y dos todavía están en crecimiento y su comportamiento productivo y reproductivo no es similar al de las hembras adultas. Adicionalmente, este agrupamiento se realizó para evitar problemas de estimabilidad. Algunas variables de respuesta fueron utilizadas como

Cuadro 1. Modelos estadísticos para algunas variables de cerdas provenientes de siete líneas genéticas

Table 1. Statistical Models for some sow variables of seven genetic lines

\begin{tabular}{lccccc}
\hline Variable & GL & NP & FR & TLSF & TLSW \\
\hline TLSF & “ & " & & & \\
TLSW & “ & " & " & & \\
PBA & " & " & & & \\
PBD & " & " & & & \\
LWF & " & & " & & " \\
LWW & " & " & " & & \\
SWL & " & " & & & \\
BFL & " & & " & \\
\hline
\end{tabular}

$\mathrm{GL}=$ Genetic line; NP= Number of parity; $F R=$ Farrowing room; TLSF= Total litter size at farrowing; TLSW = Total litter size at weaning; $\mathrm{PBA}=$ Piglets born alive; $\mathrm{PBD}=$ Piglets born dead; $L W F=$ Litter weight at farrowing; $L W W=$ Litter weight at weaning; $\mathrm{Fl}=$ Feed intake; $\mathrm{SWL}=$ Sow weight loss; $\mathrm{BFL}=$ Back fat loss. were assigned the number 1 , the three or more, number 2. No female had more than seven farrowings; females form one and two parities are still growing and their productive and reproductive performance is not similar to adult females. Additionally, this grouping was chosen to avoid estimation problems. Some response variables were used as covariates of others, depending on the variable analyzed; models are shown in Table 1. Data was analyzed using the GLM procedure of SAS(9). Means were compared using the Scheffé test (Tables 2, 3, 4 , and 5) for the statistically significant effects $(P<0.05)$.

\section{RESULTS AND DISCUSSION}

Levels of significance for the effects included in the models for the variables analyzed are in Table 2. The effect of genetic line (GL) was significant $(\mathrm{P}<0.026)$ for TLSF, PBA, PBD and $\mathrm{FI}$, the number of parity (NP) $(P=0.001)$ was only for $\mathrm{FI}$, meanwhile the effect of farrowing

Cuadro 2. Nivel de significancia para los efectos incluidos en los modelos estadísticos para algunas variables de cerdas provenientes de siete líneas genéticas

Table 2. Significance level for the effects included in the statistical models for some variables of sows from seven genetic lines

\begin{tabular}{lccccc}
\hline Variable & GL & NP & FR & TLSF & TLSW \\
\hline TLSF & $<0.0001$ & 0.2120 & & & \\
TLSW & 0.1229 & 0.6138 & 0.3117 & & \\
PBA & $<0.0001$ & 0.2120 & & & \\
PBD & $<0.0001$ & & 0.0380 & & \\
LWF & 0.1053 & 0.3092 & & $<0.0001$ & \\
LWW & 0.9203 & & 0.2664 & & $<0.0001$ \\
FI & 0.0026 & 0.0001 & 0.1385 & & \\
SWL & 0.3039 & 0.2550 & & & \\
BFL & 0.1474 & & 0.1790 & & \\
\hline
\end{tabular}

$\mathrm{GL}=$ Genetic line; NP= Number of parity; $F R=$ Farrowing room; $T L S F=$ Total litter size at farrowing; $T L S W=$ Total litter size at weaning; $\mathrm{PBA}=$ Piglets born alive; $\mathrm{PBD}=$ Piglets born dead; $\mathrm{LWF}=$ Litter weight at farrowing; $\mathrm{LWW}=$ Litter weight at weaning; $\mathrm{Fl}=\mathrm{Feed}$ intake; $\mathrm{SWL}=$ Sow weight loss; $\mathrm{BFL}=$ Back fat loss. 
PRODUCTIVIDAD AL PARTO Y AL DESTETE EN CERDAS DE SIETE LINEAS GENÉTICAS

Cuadro 3. Medias de mínimos cuadrados y error estándar para algunas variables de cerdas provenientes de siete líneas genéticas

Table 3. Least square means and standard error for some variables of sows from seven genetic lines

\begin{tabular}{lccccccccc}
\hline GL & \multicolumn{1}{c}{ TLSF } & PBA & PBD & LWF & LWW & TLSW & FI & SWL & BFL \\
\hline L- 1 & $9.4 \pm 2.5 \mathrm{ab}$ & $5.6 \pm 2.6 \mathrm{ab}$ & $3.8 \pm 0.8 \mathrm{a}$ & $12.1 \pm 3.0$ & $41.8 \pm 1.4$ & $4.2 \pm 1.2$ & $2.6 \pm 0.7 \mathrm{~b}$ & $35.2 \pm 8.7$ & $3.9 \pm 1.7$ \\
$\mathrm{~L}-2$ & $11.8 \pm 0.7 \mathrm{a}$ & $11.7 \pm 0.7 \mathrm{a}$ & $0.3 \pm 0.2 \mathrm{c}$ & $14.6 \pm 0.8$ & $43.9 \pm 0.3$ & $8.2 \pm 0.3$ & $4.9 \pm 0.2 \mathrm{a}$ & $40.4 \pm 4.4$ & $4.8 \pm 0.4$ \\
$\mathrm{~L}-3$ & $8.6 \pm 1.8 \mathrm{ab}$ & $6.9 \pm 1.8 \mathrm{ab}$ & $1.5 \pm 0.5 \mathrm{abc}$ & $11.6 \pm 2.1$ & $42.8 \pm 0.8$ & $6.9 \pm 0.9$ & $3.4 \pm 0.5 \mathrm{~b}$ & $34.4 \pm 8.7$ & $5.6 \pm 1.1$ \\
$\mathrm{~L}-4$ & $4.9 \pm 1.5 \mathrm{~b}$ & $4.1 \pm 1.5 \mathrm{~b}$ & $0.6 \pm 0.5 \mathrm{bc}$ & $6.5 \pm 1.8$ & $43.8 \pm 0.7$ & $7.6 \pm 0.7$ & $3.7 \pm 0.4 \mathrm{~b}$ & $20.7 \pm 8.7$ & $6.8 \pm 0.9$ \\
$\mathrm{~L}-5$ & $6.2 \pm 1.1 \mathrm{~b}$ & $4.8 \pm 1.1 \mathrm{~b}$ & $1.6 \pm 0.4 \mathrm{ab}$ & $7.9 \pm 1.3$ & $43.6 \pm 0.5$ & $8.1 \pm 0.5$ & $4.9 \pm 0.3 \mathrm{a}$ & $33.2 \pm 8.7$ & $4.3 \pm 0.6$ \\
$\mathrm{~L}-6$ & $8.6 \pm 1.8 \mathrm{ab}$ & $7.4 \pm 1.8 \mathrm{ab}$ & $0.5 \pm 0.5 \mathrm{bc}$ & $10.3 \pm 2.1$ & $42.8 \pm 0.8$ & $6.9 \pm 0.9$ & $3.2 \pm 0.5 \mathrm{~b}$ & $46.4 \pm 6.4$ & $5.1 \pm 1.1$ \\
$\mathrm{~L}-7$ & $9.5 \pm 0.6 \mathrm{ab}$ & $9.3 \pm 0.6 \mathrm{ab}$ & $0.1 \pm 0.2 \mathrm{c}$ & $11.9 \pm 0.7$ & $43.4 \pm 0.3$ & $7.7 \pm 0.3$ & $4.8 \pm 0.2 \mathrm{a}$ & $33.9 \pm 2.8$ & $4.0 \pm 0.4$ \\
\hline
\end{tabular}

$\mathrm{GL}=$ Genetic line; TLSF $=$ Total litter size at farrowing; $\mathrm{PBA}=$ Pigs born alive; $\mathrm{PBD}=$ Pigs born dead; $L W F=L i t t e r$ weight at Farrowing; $L W W=$ Litter weight at weaning; $T L S W=$ Total litter size at weaning; $F I=$ Feed intake; $S W L=S o w$ weight loss, $B F L=$ Back fat loss.

abc Values with different superscript in columns differ $(P<0.05)$.

covariables de otras, dependiendo de la variable analizada, los modelos se indican en el Cuadro 1. La información se analizó mediante el procedimiento GLM de SAS(9). Se realizó una comparación múltiple de medias utilizando la prueba de Scheffe (Cuadros 2,3,4,5) para los efectos estadísticamente significativos $(P<0.05)$.

\section{RESULTADOS Y DISCUSIÓN}

En el Cuadro 2 se presentan los niveles de significancia para los efectos considerados en los modelos para las variables analizadas. El efecto de línea genética (LG) fue significativo $(\mathrm{P}<0.026)$ para TCN, TCNV, LNM y CDA; el número de parto (NP) lo fue $(P=0.001)$ sólo para CDA, mientras que el efecto de sala de parto (S) lo fue $(P=0.380)$ para $L N M$. La covariable TCN fue importante $(P<0.001)$ para $P C N$ y TCD lo fue $(P<0.001)$ para $P C D)$.

Tamaño la camada al nacimiento, tamaño de la camada nacida viva y número de lechones nacidos muertos por camada

Considerando la información de todas las líneas genéticas, el tamaño de la camada al nacimiento y de la camada nacida viva pueden considerarse relativamente bajos comparados con los obtenidos en otros estudios $(7,10)$. Las líneas room (FR) was for $\mathrm{PBD}(\mathrm{P}=0.380)$. PBA covariate was important $(P<0.001)$ for LWF and TLSW $(P<0.001)$ for $L W W)$.

Total litter size at farrowing, size of the litter born alive and number of dead piglets born per litter

Based on the information of all genetic lines, litter size at farrowing and litter born alive can be considered relatively low compared with those obtained in other studies $(7,10)$. The genetic lines with the higher TLSF were L-2, L-7, and L- 1 with least square means (LSM) of $11.8 \pm$ $0.7,9.5 \pm 0.6$ to $9.4 \pm 2.5$ piglets, respectively (Table 3). Galvin et al(11) reported 15.9 piglets for TLSF in Large White sows. In another study(1) it was found an average of $10.75 \pm$ 0.56 piglets, similar to that obtained in the present study. Similarly, in a study conducted with Landrace and Large White sows, there were averages for TLSF of 10.45 and 10.76 piglets, respectively(12).

Although the difference was not significant $(P>0.2120)$, contrary to other studies(13), sows grouped in parity two had higher TLSF (8.8 \pm $0.6)$ versus those grouped in parity one (7.9 \pm 0.8 , Table 2). In studies in which the difference in favor of females of three or more parities 
genéticas que tuvieron las mayores TCN fueron L-2, L-7 y L-1 con medias de mínimos cuadrados (MMC) de $11.8 \pm 0.7,9.5 \pm 0.6$ y $9.4 \pm 2.5$ lechones, respectivamente (Cuadro 3). Galvin et al(11) reportaron 15.9 lechones para TCN en cerdas Large White. En otro estudio(1) encontraron un promedio de $10.75 \pm 0.56$ lechones, similar al obtenido en el presente estudio. De manera similar, en un estudio realizado con hembras Landrace y Large White(12) observaron promedios para TCN de 10.45 y 10.76 lechones, respectivamente.

Aunque la diferencia no fue significativa $(P>0.21)$, contrario a lo encontrado en otros estudios(13), las hembras agrupadas en el parto dos tuvieron mayor TCN $(8.8 \pm 0.6)$ que las agrupadas en el parto uno ( $7.9 \pm 0.8$, Cuadro has been significant, it was explained by the greater uterine size capacity, ovulation rate and embryo survival(10). Similarly Koketsu et al(13), observed a better reproductive performance in sows with equal to or greater than two parities compared to sows of first parity.

Sows of the L-2 line had the largest LSM for PBA with $11.7 \pm 0.7$ (Table 3 ). The difference between TLSF and PBA was greater for sows of the $L-1$ line, which may result from an increase in intrapartum deaths for insufficient attention at farrowing. Females of parity 3 to 7 had higher PBA 1.1 (16.7\%) than females of first and second parities (Table 4). Although this difference was not significant $(P>0.2120)$, the result may be due to chance or by sampling error; because females of 3 or more parities

Cuadro 4. Medias de mínimos cuadrados y error estándar para algunas variables de cerdas provenientes de siete líneas genéticas de acuerdo al número de parto

Table 4. Least square means and standard error for some variables of sows from seven genetic lines according to number of parity

\begin{tabular}{lcccccc}
\hline NP & TLSF & PBA & LWF & TLSW & FI & SWL \\
\hline 1 & $7.9 \pm 0.8$ & $6.6 \pm 0.8$ & $10.3 \pm 0.9$ & $7.2 \pm 0.4$ & $3.4 \pm 0.2$ b & $37.8 \pm 4.4$ \\
2 & $8.8 \pm 0.6$ & $7.7 \pm 0.6$ & $11.1 \pm 0.8$ & $7.0 \pm 0.3$ & $4.5 \pm 0.2$ a & $32.0 \pm 3.0$ \\
\hline
\end{tabular}

$\mathrm{NP}=$ Number of parity; TLSF= Total litter size at farrowing; $\mathrm{PBA}=\mathrm{Pigs}$ born alive; LWF $=$ Litter weight at farrowing; TLSW $=$ Total litter size at weaning; $\mathrm{FI}=$ Feed intake; SWL= Sow weight loss.

ab Values with different superscript in columns differ $(P<0.05)$.

Cuadro 5. Medias de mínimos cuadrados y error estándar para algunas variables de cerdas provenientes de siete líneas genéticas de acuerdo a la sala de parto

Table 5. Least square means and standard error for some variables of sows from seven genetic lines according to the farrowing room

\begin{tabular}{lccccc}
\hline FR & PBD & LWW & TLSW & FI & BFL \\
\hline 1 & $1.5 \pm 0.3 \mathrm{ab}$ & $43.8 \pm 0.4$ & $7.7 \pm 0.4$ & $4.3 \pm 0.2$ & $5.4 \pm 0.5$ \\
2 & $1.8 \pm 0.3 \mathrm{a}$ & $43.1 \pm 0.5$ & $7.2 \pm 0.5$ & $3.8 \pm 0.3$ & $4.9 \pm 0.6$ \\
3 & $0.6 \pm 0.3 \mathrm{~b}$ & $43.5 \pm 0.5$ & $7.2 \pm 0.5$ & $4.2 \pm 0.3$ & $5.7 \pm 0.6$ \\
4 & $0.9 \pm 0.2 \mathrm{ab}$ & $42.9 \pm 0.5$ & $6.8 \pm 0.4$ & $3.4 \pm 0.3$ & $4.0 \pm 0.6$ \\
5 & $1.2 \pm 0.3 \mathrm{ab}$ & $42.3 \pm 0.5$ & $6.6 \pm 0.5$ & $3.9 \pm 0.3$ & $4.6 \pm 0.7$ \\
\hline
\end{tabular}

$\mathrm{FR}=$ Farrowing room; $\mathrm{PBD}=$ Piglets born dead; $\mathrm{LWW}=$ Litter weight at weaning; TLSW = Total litter size at weaning; $\mathrm{Fl}=$ Feed intake; $\mathrm{BFL}=$ Back fat loss.

ab Values with different superscript in columns differ $(P<0.05)$. 
2). En los estudios en que la diferencia a favor de las hembras de tres o más partos ha sido significativa, se ha explicado por el mayor tamaño, capacidad uterina, tasa de ovulación y sobrevivencia embrionaria(10). De manera similar Koketsu et al(13), observaron un mejor desempeño reproductivo en cerdas con número de parto igual o mayor que dos comparado con las de primer parto.

Las cerdas de la línea L-2 tuvieron la mayor media para TCNV con $11.7 \pm 0.7$ (Cuadro 3). La diferencia entre TCN y TCNV fue mayor para las cerdas de la línea L-1, lo cual puede resultar de un aumento en las muertes "intrapartum" por insuficiente atención al parto. Las hembras del parto tres a siete tuvieron TCNV 1.1 mayor ( $16.7 \%$ ) que las hembras de primero y segundo partos (Cuadro 4). Aunque esta diferencia no fue significativa $(P>0.21)$, el resultado puede deberse al azar o por error de muestreo; cabría esperarse que lo fuera, ya que las hembras a los tres o más partos han alcanzado la madurez de crecimiento y tienen mayor capacidad uterina y de ovulación que las de primero y segundo partos $(14,15)$. En el estudio de Ruíz-Flores(16) se observó TCNV de 9.5 a 11.7, de 9.1 a 10.8 y de 6.6 a 9.1 lechones en tres líneas genéticas en un experimento de selección en dos etapas para tasa de ovulación y número de cerdos completamente formados al nacimiento.

Para LNM, la diferencia entre las líneas genéticas con mayor (L-1) y menor (L-7) MMC fue 3.7 lechones (Cuadro 3). Sin embargo, LNM no puede atribuirse completamente a la cerda, ya que los lechones pudieron haber muerto por falta de atención al parto, posiblemente debida a diferencias en cuidados de los encargados, $u$ otras causas no genéticas. Aproximadamente $74 \%$ de los lechones nacidos muertos se deben a aspectos de manejo y el $26 \%$ a causas genéticas(17). Contrario a lo observado en el presente estudio, Serenius et al(12), observaron en las razas Landrace y Large White, promedios para LNM de 0.80 y 0.86 , respectivamente. En otro estudio(16) se encontró de 1.0 a 3.9, de have reached growth maturity and have greater uterine capacity and ovulation ability $(14,15)$. In the work of Ruiz-Flores(16) it was observed PBA of 9.5 to $11.7,9.110 .8$ and 6.6 to 9.1 in three genetic lines in a selection experiment, in two stages for ovulation rate and number of pigs fully formed at birth.

For $\mathrm{PBD}$, the difference between the genetic lines with highest (L-1) and lowest (L-7) LSM was 3.7 piglets (Table 3 ). However, PBD is not attributable entirely to the sow, because the piglet could have died for lack of attention at birth, possibly due to differences in care of worker, or other non-genetic causes. Approximately $74 \%$ of the dead-born piglets are due to management aspects and $26 \%$ to genetic causes(17). Contrary to what was observed in the present study, Serenius et al(12), observed in Landrace and Large White, averages for PBD of 0.80 and 0.86 , respectively. In another study(16) there were found 1.0 to $3.9,0.5$ to 1.1 and 0.3 to 0.7 piglets born dead in three genetic lines.

The effect of farrowing room, which was significant $(P<0.0380)$ for PBD (Table 5), considers factors of management such as temperature, feeding, care from the manager and ventilation, among others(18).

Birth litter weight, weaning litter weight and weaning litter size

None of the factors included in the models for these variables were significant $(P>0.1053$; Table 2), although TLSF and TLSW covariates were significant $(\mathrm{P}<0.0001)$ for LWF and LWW, respectively. Litters' homogenization within $48 \mathrm{~h}$ after birth explains the results for LWW and TLSW. In commercial production, crossing adoption depending on the female's potential, is a recommended practice(19).

Sows with higher TLSF had also heavier litters at birth (Table 3); the difference between the heaviest litters ( $L-2)$ and the lightest ( $L-4)$ was $8.1 \mathrm{~kg}$. LWF from 11.9 to $15.2 \mathrm{~kg}$, from 10.8 to $12.9 \mathrm{~kg}$ and 8.7 to $12.9 \mathrm{~kg}$ were found in a study with sows of three genetic lines(16). 
0.5 a 1.1 y de 0.3 a 0.7 lechones nacidos muertos en tres líneas genéticas.

El efecto de sala de parto, que fue significativo $(P<0.03)$ para LNM (Cuadro 5), considera factores de manejo como temperatura, alimentación, cuidados del encargado y ventilación, entre otros(18).

Peso de la camada al nacimiento, peso de la camada al destete y tamaño de la camada al destete

Ninguno de los factores incluidos en los modelos para estas variables fueron significativos ( $P>0.10$; Cuadro 2), aunque las covariables TCN y TCD sí lo fueron $(P<0.0001)$ para $P C N$ y $P C D$, respectivamente. Para PCD y TCD estos resultados pueden explicarse por la homogenización de camadas que se realiza dentro de 48 h después del parto. La adopción cruzada en función del potencial de las hembras, es una práctica recomendable en producción comercial(19).

Las cerdas que tuvieron las mayores TCN también tuvieron las camadas más pesadas al nacimiento (Cuadro 3); la diferencia entre las camadas más pesadas ( $L-2)$ y las más ligeras (L-4) fue $8.1 \mathrm{~kg}$. En un estudio con cerdas de tres líneas genéticas se encontraron PCN de 11.9 a $15.2 \mathrm{~kg}$, de 10.8 a $12.9 \mathrm{~kg}$ y de 8.7 a $12.9 \mathrm{~kg}(16)$.

La diferencia por NP para PCN no fue significativa $(P>0.30)$; en trabajos donde se ha encontrado significativo este efecto $(14,15)$ se ha explicado por el mayor TCN generalmente asociado con hembras de mayor número de parto.

El PCD fue similar en todas las líneas genéticas (Cuadro 3); este resultado refleja un manejo y nutrición similar en la lactancia, y la homogenización de las camadas al parto. Cuando el destete se realiza a una misma edad, el peso de la camada al destete depende principalmente del número de lechones destetados. En un estudio con cerdas de tres líneas genéticas se observaron PCD de 49.5 a 56.2, de 53.4 a 61.5 y de 50.3 a $61.5 \mathrm{~kg}$, cuando se destetó a 28 d;
The difference in LWF for PN was not significant $(P>0.30)$; in studies where this effect was significant $(14,15)$ it was explained by the TLSF more usually associated with females of higher parity.

The LWW was similar in all the genetic lines (Table 3); this result reflects a similar management and nutrition during lactation, and standardization of the litters at farrowing. When weaning occurs at the same age, the litter weight depends mainly on the number of weaned piglets. LWW from 49.5 to 56.2 , from 53.4 to 61.5 and from 50.3 to $61.5 \mathrm{~kg}$, were observed in a study with three genetic lines when weaning occurred at $28 \mathrm{~d}$; and weights of 43.9, 44.1 and $43.9 \mathrm{~kg}$ for pigs weaned at $21 \mathrm{~d}(16)$. In another study (20), it was also observed that the LWW increased $(P<0.05)$ as the lactation length increased, from $40.32 \pm 1.35 \mathrm{~kg}$ with 1 to $7 \mathrm{~d}$ lactations, to $64.01 \pm 0.52 \mathrm{~kg}$ when lactation was equal to or greater than $29 \mathrm{~d}$.

For TLSW, although the effect of genetic line was not significant $(P>0.1229)$ it shows a tendency of the $L-2, L-5$ and $L-7$ lines to express greater LSM for TLSW, $8.2 \pm 0.3,8.1 \pm 0.5$ and $7.7 \pm 0.3$ piglets, respectively (Table 3 ). However, L-5 was one with the lowest TLSF, what explains this is the piglet standardization at farrowing. RuizFlores(16) observed from 7.0 to $9.1,9.4$ to 7.8 and 6.4 to 9.2 piglets weaned per litter in three genetic lines. The effect of farrowing room was neither significant $(P>0.3117)$; other components included room temperature, food, micro-environment with external source of heat for piglets and the care of maternity worker, among others. Roppa(21) considered that the relationship between sows and their caregivers is one of the most important factors to improve production parameters during lactation.

Daily sow food intake, weight and back fat loss during lactation

The effects of genetic line and number of parity only influenced $(P<0.0026)$ FI (Table 2$)$. Sows 
mientras que cuando se hizo a $21 \mathrm{~d}$, los promedios fueron $43.9,44.1$ y $43.9 \mathrm{~kg}^{(16)}$. En otro estudio(20), también se observó que el PCD se incrementó $(P<0.05)$ conforme el largo de lactancia aumentó, de $40.32 \pm 1.35 \mathrm{~kg}$ con lactancias de 1 a $7 \mathrm{~d}$, hasta $64.01 \pm 0.52 \mathrm{~kg}$ con lactancia iguales o mayores a $29 \mathrm{~d}$.

Para TCD, aunque el efecto de línea genética no fue significativo $(P>0.12)$ se nota una tendencia de las líneas L-2, L-5 y L-7 a expresar mayores MMC para TCD, $8.2 \pm 0.3,8.1 \pm 0.5$ y $7.7 \pm 0.3$ lechones, respectivamente (Cuadro 3). Sin embargo, L-5 tuvo uno de los menores TCN, lo que explica esto es la adopción cruzada de lechones entre camadas al parto. RuízFlores(16) observó de 7.0 a 9.1, de 7.8 a 9.4 y de 6.4 a 9.2 lechones destetados por camada en tres líneas genéticas. El efecto de sala de parto tampoco resultó significativo $(P>0.31)$. Los componentes del efecto de sala de parto incluyen temperatura de la sala, alimentación, microambiente con fuente externa de calor para los lechones y los cuidados del encargado de la maternidad, entre otros. Roppa(21) considera que la relación entre cerdas y sus cuidadores es uno de los factores más importantes para mejorar los índices productivos durante la lactancia.

Consumo diario de alimento de la cerda, pérdida de peso y pérdida de grasa dorsal en la lactancia

Los efectos de línea genética y número de parto sólo influyeron $(P<0.002)$ en CDA (Cuadro 2). Las cerdas de la línea L-4 presentaron mayor PGD durante la lactancia (Cuadro 3), resultado que no corresponde al comportamiento productivo mostrado por cerdas de esta línea, ya que no destetaron las camadas más grandes o más pesadas, y tampoco tuvieron los menores consumos de alimento, lo que posiblemente hubiera causado pérdida de grasa dorsal. De acuerdo con los tamaños de camada que las cerdas amamantaron, se esperaban consumos diarios de alimento mayores que los obtenidos, esto es lo que puede explicar las PPL y PGD of line L-4 presented higher BFL during lactation (Table 3), a result that does not correspond to the productive performance shown by sows of this line, because they did not weaned litters larger or heavier, and nor had lesser feed intake, what would have possibly caused back fat loss. According to the litter size that the sows of the study raised, daily feed intakes were lower than those, expected, and this may explain the SWL and BFL observed, which in turn may delay the sows returning into estrus after weaning(4). Contrasting the results of this study, Koketsu et al(13) found that feed intake during lactation equal to or greater than $5.7 \mathrm{~kg}$ compensates the negative effects of the lactation length over the farrowing rate. Other study(4) found that although there was not a reduction in the lactation performance or ovarian function when the sows lost approximately 9.0 to $12.0 \%$ of their weight at calving; however, if losses continue, the animal performance decreases.

With regard to the effect of the farrowing room on $\mathrm{Fl}$, the difference between the highest and lowest consumption was $0.9 \mathrm{~kg}$ of food per day (Table 5), this can be attributed to the environmental rooms conditions, mainly temperature and ventilation(22). Sows housed in room 3 had the highest BFL $(5.7 \pm 0.6 \mathrm{~mm})$, and room 4 the lowest (4.0 $\pm 0.6 \mathrm{~mm}$; Table 5).

Sows from 3 to 7 parity consumed $1.1 \mathrm{~kg} \mathrm{~d}^{-1}$ more food compared to first and second parities (Table 4). This can be considered normal because adult females have higher maintenance needs due to greater body size(15), and its higher milk production.

\section{CONCLUSIONS AND IMPLICATIONS}

The sows of the seven genetic lines differ in litter size at birth, in total piglets born alive, daily feed intake and number of piglets born dead per litter. Sows of three or more parities had increased feed intake than those of first or second. Better care at farrowing and during lactation may reduce piglets' death, as well as the loss of weight and back fat, reducing the 
observadas, lo que a su vez puede retrasar la entrada de las cerdas al celo después del destete(4). Contrastando los resultados de este estudio, Koketsu et al(13) encontraron que el consumo de alimento durante la lactancia igual o mayor de $5.7 \mathrm{~kg}$ compensa los efectos negativos de la duración de la lactancia en la tasa de parición. En otro estudio(4) encontraron que aunque no hubo una reducción en el comportamiento en la lactancia o la función ovárica cuando las cerdas pierden aproximadamente del 9.0 al $12.0 \%$ de su peso al parto; sin embargo, cuando esta pérdida continúa, se asocia un decremento en el comportamiento animal.

Con relación al efecto de sala de maternidad en el CDA, la diferencia entre el mayor y menor consumo fue de $0.9 \mathrm{~kg}$ de alimento/día (Cuadro $5)$; esto puede deberse a las condiciones ambientales de las salas, principalmente la temperatura y la ventilación(22). Las cerdas alojadas en la sala 3 tuvieron la mayor PGD $(5.7 \pm 0.6 \mathrm{~mm})$, y en la 4 la menor $(4.0 \pm 0.6$ $\mathrm{mm}$; Cuadro 5).

Las hembras de tres a siete partos consumieron $1.1 \mathrm{~kg}$ alimento $\mathrm{d}^{-1}$ más, comparado con las de primero y segundo partos (Cuadro 4). Esto puede considerarse normal pues las hembras adultas tienen que cubrir necesidades mayores para mantenimiento por su mayor tamaño corporal(15), y su producción láctea es mayor.

\section{CONCLUSIONES E IMPLICACIONES}

Las cerdas de las líneas genéticas estudiadas difieren en el tamaño de la camada al nacimiento, en el número total de lechones nacidos vivos, en el número de lechones nacidos muertos por camada y en consumo diario de alimento. Las cerdas de tres o más partos tuvieron mayor consumo de alimento que las de primero o segundo. Una mejor atención al parto y durante la lactancia podría reducir la muerte intrapartum de lechones y durante la lactancia, así como las pérdidas de peso y grasa dorsal, reduciendo el deterioro en el low productive and reproductive performance post weaning.

End of english version

comportamiento productivo y reproductivo postdestete.

\section{LITERATURA CITADA}

1. Ate IU, Oyedipe EO. Sow reproductive performance in Institutional Herds in Benue State, Nigeria. J Reprod Infert 2011;2:24-31.

2. Holm B, Bakken M, Vangen O, Rekaya R. Genetic analysis of age at first service, return rate, litter size, and weaningto-first service interval of gilts and sows. J Anim Sci 2005; 83:41-48.

3. Everts $H$, Dekker RA. Effect of protein supply during pregnancy and lactation on body composition of sows during three reproductive cycles. Livest Prod Sci 1995; 43: 137-147.

4. Clowes EJ, Aherne FX, Foxcroft GR, Baracos VE. Selective protein loss in lactating sows is associated with reduced litter growth and ovarian function. J Anim Sci 2003;81:753764.

5. Murillo GC, Herradora LMA, Martinez GR. Relación entre la pérdida de grasa dorsal de cerdas lactantes con el consumo de alimento, tamaño de la camada, peso de los lechones al destete y días de Lactancia. Rev Cient (Maracaibo) 2007; 17:380-385.

6. Sulbaran L, Araque H, González C, Mora F. Comportamiento productivo de cerdos nacidos y terminados en cuatro modalidades distintas de alojamientos. Revista Científica FCV-LUZ 2009;29:49-54.

7. Segura CJC, Alzina-López A, Solorio RJL. Evaluación de tres modelos y factores de riesgo asociados a la mortalidad de lechones al nacimiento en el trópico de México. Tec Pecu Méx 2007; 45:227-236.

8. García E. Modificaciones al Sistema de Clasificación Climática de Köppen. Editorial Larios. México, D.F. 1988.

9. SAS. SAS/STAT User's Guide (Release 9.20). SAS Inst. Inc. Cary, N.C. 2012.

10. Ruiz-Flores A, Johnson RK. Direct and correlated responses to two-stage for ovulation rate and number of fully formed pigs in swine. J Anim Sci 2001;79:2286-2297.

11. Galvin J M, Wilmut I, Day BN, Ritchie M, Thomson M, Haley CS. Reproductive performance in relation to uterine an embryonic traits during early gestation in Meishan, Large White, and crossbred sows. J Reprod Fert 1993;98:103.

12. Serenius $T$, Sevon-Aimónen ML, Kause A, Mäntysaari EA, Mäki-Tanila A. Genetic associations of prolificacy with performance, carcass, meat quality and leg conformation traits in the Finnish Landrace and Large White pig populations. J Anim Sci 2004;82:2301-2306. 
13. Koketsu Y, Dial GD, King VL. Influence of various factors on farrowing rate on farms using early weaning. J Anim Sci 1997; 75:2580-2587.

14. English PR, Fowler VR, Baxter S, Smith WJ. La cerda: como mejorar su productividad. $2^{\mathrm{a}}$ ed. México, DF: Editorial El Manual Moderno; 1995.

15. Whittemore CT. The sciencie and practice of pig production. $2^{\text {nd }}$ ed. London, England: Blackwell Sciencie Ltd; 1998.

16. Ruíz-Flores A. Direct and correlated responses to two-stage selection for ovulation rate and number of fully formed pigs at birth [PhD thesis] University of Nebraska-Lincoln. Lincoln, NE. 2000.

17. Bolet G, Martinat-Botté F, Locatelli A, Gruand J, Terqui M, Berthelot F. Components of prolificacy in hyperprolific Large White sows compared with the Meishan and Large White breeds. Genet Sel Evol 1986;18:333-342.
18. Colzer Y, Dagon J, Guyomarch C, Pichodo X, Quinio P. Causas del nacimiento de lechones muertos. Disponible en: http:/ /www. Porcicultura.com/. Consultada 22 Feb, 2013.

19. Quiles A, Hevia M. Recomendaciones para la adopción de lechones. http://www.porcicultura.com/. Consultada 20 Feb, 2013.

20. Koketsu Y, Dial GD. Factors influencing the postweaning reproductive performance of sows on commercial farms. Theriogenology 1997; 47:1445-1461.

21. Roppa L. Relación entre las cerdas y sus cuidadores y su efecto sobre el rendimiento productivo. http:// www. porcicultura.com/. Consultada 22 Feb, 2013.

22. Ahlschwede TW, How A, Reese D. Cuidado de la cerda durante el parto. http://www. porcicultura.com/. Consultada 24 Feb, 2012. 
